\title{
Winter cover crops affecting physical and chemical soil attributes in a commercial vineyard
}

\author{
Milton da Veiga ${ }^{*}$ Nelson Pires Feldberg ${ }^{2}$ Gilberto Nava $^{3}$ Jean Carlos Bettoni ${ }^{4}$
}

\footnotetext{
${ }^{1}$ Universidade do Oeste de Santa Catarina (UNOESC), 89620-000, Campos Novos, SC, Brasil. E-mail: milton.veiga@unoesc.edu.br. ${ }^{*}$ Corresponding author.

${ }^{2}$ Empresa Brasileira de Pesquisa Agropecuária (EMBRAPA), Canoinhas, SC, Brasil.

${ }^{3}$ Centro de Pesquisa Agropecuária de Clima Temperado (CPAT), Empresa Brasileira de Pesquisa Agropecuária (EMBRAPA), Pelotas, RS, Brasil. ${ }^{4}$ Centro de Ciências Agroveterinárias (CAV), Universidade do Estado de Santa Catarina (UDESC), Lages, SC, Brasil.
}

\begin{abstract}
Cover crops may have direct or indirect effects on the physical and chemicalsoil attributes; these cropsplay a key role in the cycling of nutrients in the soil and add labile organic carbon, bringing economic and environmental benefits to the system. To study the effect of cover crops on the physical and chemical properties of an Oxisol, a three-year experiment was conducted in a commercial vineyard located at Epagri's Experimental Station in Videira, SC, Brazil. Different winter species (white clover, red clover, common vetch, turnip, corn spurrey, black oat, rye, and ryegrass) were sown in addition to treatments with manual weeding or mechanical mowing. Certain chemical and physical attributes of soil were determined in samples collected fromlayers 0-0.1 and 0.1-0.2m deep on the vinerows and between rows, as well as the dry mass of winter cover crops. Few chemical and physical attributes of the soil changed among winter cover crops and did not differ from the crops managed with mechanical mowing or hand weeding of spontaneous vegetation. Vine rows provided more adequate values of most physical and chemical soil attributes.

Key words: organic matter, nutrients, bulk density, soil porosity, Vitis spp.
\end{abstract}

Plantas de cobertura de inverno afetando atributos químicos e físicos do solo em vinhedo comercial

RESUMO: As plantas de cobertura podem apresentar efeitos diretos ou indiretos sobre os atributos fisicos e químicos do solo, desempenhando papel fundamental na ciclagem dos nutrientes e na adição de carbono orgânico lábil ao solo, trazendo beneficios econômicos e ecológicos ao sistema. Para estudar o efeito de plantas de cobertura sobre os atributos físicos e químicos de um Nitossolo Vermelho, foi conduzido por três anos um experimento com semeadura de diferentes espécies de inverno (trevo-branco, trevo-vermelho, ervilhaca-comum, nabo-forrageiro, espérgula, aveia-preta, centeio e azevém), além dos tratamentos com capina manual e roçada mecânica, em um vinhedo comercial localizado na Estação Experimental da Epagri em Videira, SC. Foram determinados alguns atributos químicos e físicos do solo em amostras coletadas nas camadas de 0-0,1 e 0,1-0,2m de profundidade na linha e na entrelinha da cultura, além da massa seca das plantas de cobertura de inverno. As plantas de cobertura do solo alteram poucos atributos químicos e fisicos do solo e não se diferenciam do manejo da vegetação espontânea com capinas manuais ou com roçadas mecânicas. A linha da cultura apresenta valores mais adequados da maioria dos atributos físicos e químicos do solo.

Palavras-chave: matéria orgânica, nutrientes, densidade do solo, porosidade do solo, Vitissp.

\section{INTRODUCTION}

The use of cover crops in vineyards in southern Brazil has increased significantly in recent years, with the aim of reducing erosion as well as improving the chemical, physical, and biological soil quality. Cover crops can also assist in the nutritional management of the vine and in pest and weed control.
Cover crops may directly affect the soil's physical properties through mechanical action of its root system, or indirectly by promoting soil cover and intake of plant residues. Generally, no changes in bulk density and total porosity have been observed with the use of winter cover crops in croplands (LAURANI et al., 2004; NICOLOSO et al., 2008; SILVEIRA JUNIOR et al., 2012) or in vineyards (DALLA ROSA 
et al., 2013). However, DALLA ROSA et al. (2013) observed that the management of cover crops by mowing showed higher aggregate stability than when they are desiccated. These authors also reported an increase in bulk density and a reduction in volume of biopores, filled porosity, and total porosity in inter-rows as a result of surface soil compaction by machinery traffic and cultivation equipment. This effect is directly related to the intensity of traffic between rows, as also observed by VALOIS et al. (2014) in vineyards on Santa Catarina Coast.

Cover crops play a key role in nutrient cycling in the soil and add labile organic carbon to the system, bringing economic benefits with minimal long-term impact on the soil and on water and air quality (REICOSKY \& FORCELLA, 1998). Few differences in $C$ dynamics between cover crops were observed by STEENWERTH \& BELINA (2008), but cover crops were more effective at adding soil $\mathrm{C}$ than soil cultivation. One of the most significant effects of the use of cover crops is to increase the organic matter content in the topsoil (SMITH et al., 2008; LOPES et al., 2011), which is reflected in the increase of the $\mathrm{pH}$-dependent charges in tropical soils (MEURER et al., 2010) and, consequently, an increased ability to retain nutrients. Proving this assertion, FARIA et al. (2004) observed an increase in the soil's organic matter, cation exchange capacity, and exchangeable $\mathrm{Ca}$ content in the $0-0.1 \mathrm{~m}$ soil layer with the use of cover crops in a sandy soil in the Valley of the São Francisco River. However, there is a differential effect between cover crop species with regard to their organic carbon addition to the system (STEENWERTH \& BELINA, 2008), mainly due to the fact that the species used as cover crops in vineyards have a differentiated capacity to establish within the vineyards, and may even produce less biomass compared to the weeds that occur spontaneously in the area (BUGG et al., 1996).

Some species used as cover crops have a suppressive effect on weed and can replace preemergence herbicides (VAN HUYSSTEEN et al., 2017). In a study on weed control and grape yield with coverage management, BORDELON \& WELLER (1997) observed a reduction of weed infestation in up to $95 \%$ in cover crops when compared to the control crop. Additionally, significant effects of the covercrop systems can be observed on weed biomass, community structure, or diversity in the inter-rows but not in the intra-rows (BAUMGARTNER et al., 2008). This effect is most pronounced at the start of the following season, when most species are effective in suppressing weeds (OLMSTEAD et al., 2001).
As the use of winter cover crops in vineyards is a recent practice in the Santa Catarina State, southern Brazil, it is necessary to perform studies in order to verify the crops' effects on soil attributes and weed control, and associate them to factors related to crop production both in vine rows and inter-rows.

\section{MATERIALS AND METHODS}

The experiment was conducted in a commercial vineyard at the Epagri Experiment Station in Videira, SC, with geographical coordinates $27^{\circ} 02^{\prime} 04^{\prime \prime} \mathrm{S}$ and $51^{\circ} 08^{\prime} 05^{\prime \prime} \mathrm{W}$, and with an average altitude of $834 \mathrm{~m}$. The soil of the study area is an Oxisol (Nitossolo Vermelho Distrófico in the Brazilian soil survey system) (EMBRAPA, 2004), and the climate is mesothermal humid with mild summers, type $\mathrm{Cfb}$ according to Köppen classification (PANDOLFO et al., 2002). The vineyard of Cabernet Sauvignon on the 1103 Paulsen rootstock was implanted in 1999, 10 years before the beginning of the experiment, and conducted in the form of trellises with weed control by continuous mechanical mowing between rows and hand weeding on the crop rows.

Treatments consisted of different soil management in the winter, with hand weeding and mechanical mowing of weeds in the entire plot, or the planting of eight species of winter cover crops (white clover, red clover, common vetch, turnip, corn spurrey, black oat, rye, and ryegrass), arranged in randomized complete block design with four replications. The cover crops were sown by broadcasting across the plot area with a mild merger with a hoe, and managed by mowing at their full bloom. The control of weeds during the summer season was performed by hand weeding on rows and mechanical mowing between rows (inter-rows). In the table 1 are shown de dry mass production of the cover crops and weeds (spontaneous vegetation) in the winter season before soil sampling.

Up until the beginning of the experiment, only the vine rows were fertilized. The experiment consisted of applying, in the total area, $150 \mathrm{~kg} \mathrm{ha}^{-1} \mathrm{~N}$ as urea, $100 \mathrm{~kg} \mathrm{ha}^{-1} \mathrm{P}_{2} \mathrm{O}_{5}$ as triple superphosphate, and $120 \mathrm{~kg} \mathrm{ha}^{-1} \mathrm{~K}_{2} \mathrm{O}$ as potassium chloride. About $50 \%$ $\mathrm{P}$ and $25 \% \mathrm{~K}$ were applied at cover crop seeding, and were associated with the application of $1.5 \mathrm{t} \mathrm{ha}^{-1}$ dolomitic limestone. The remainder of the fertilizer dose was applied three times during the vegetative vine cycle, starting about 15 days after sprouting and extending until the change in color of the berries.

The collection of soil samples for chemical and physical analyses was performed in the third year 
Table 1 - Dry matter production of winter cover crops and weeds in the winter before soil sampling.

\begin{tabular}{|c|c|c|c|}
\hline \multirow{3}{*}{ Treatment } & & & \\
\hline & Cover crop & Weeds & Total \\
\hline & \multicolumn{3}{|c|}{ 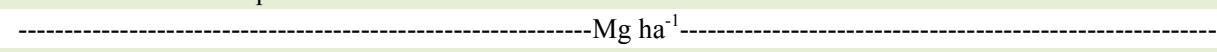 } \\
\hline Manual weeding & $0,00 \mathrm{c}$ & $0,00 \mathrm{c}$ & $0,00 \mathrm{e}$ \\
\hline Mechanical mowing & $0,00 \mathrm{c}$ & $0,00 \mathrm{c}$ & $0,00 \mathrm{e}$ \\
\hline White clover & $0,26 \mathrm{c}$ & $3,60 \mathrm{ab}$ & $3,86 \mathrm{~d}$ \\
\hline Red clover & $0,31 \mathrm{c}$ & 4,20ab & $4,51 \mathrm{~cd}$ \\
\hline Turnip & $2,63 b$ & $2,14 b c$ & $4,77 \mathrm{~cd}$ \\
\hline Corn spurrey & $2,67 b$ & $5,01 \mathrm{a}$ & $7,74 \mathrm{ab}$ \\
\hline Common vetch & $4,13 \mathrm{ab}$ & $3,75 \mathrm{ab}$ & $7,88 \mathrm{a}$ \\
\hline Black oat & $3,52 \mathrm{ab}$ & $2,29 \mathrm{ab}$ & $5,81 \mathrm{bcd}$ \\
\hline Rye & $4,64 \mathrm{ab}$ & $0,52 \mathrm{c}$ & $5,16 \mathrm{~cd}$ \\
\hline Ryegrass & $5,25 \mathrm{a}$ & $1,22 \mathrm{c}$ & $6,46 a b c$ \\
\hline
\end{tabular}

Means followed by the same letter in the column do not differ significantly (Tukey test, $\mathrm{P}<0.05$ ).

of the experiment. Samples for the chemical analyses were collected with a Dutch auger type in layers 0-0.1 and $0.1-0.2 \mathrm{~m}$ deep at four points per plot along the vine row and in the center of the inter-row; together, the collections formed a composite sample for each position and layer of each plot. In these samples, $\mathrm{pH}$ in water, organic matter, extractable $\mathrm{P}, \mathrm{Cu}$, and $\mathrm{Zn}$, and exchangeable $\mathrm{Al}, \mathrm{K}, \mathrm{Ca}$, and $\mathrm{Mg}$ were determined using the methodologies described in TEDESCO et al. (1995). The cation exchange capacity and the base saturation from these results were also calculated, using the methodology of the same authors.

Samples for physical analysis were collected in volumetric rings at one point on the vine row and at another in the center of the inter-row in each plot at layers $0.02-0.07$ and $0.12-0.17 \mathrm{~m}$ deep. In these samples, bulk density, penetration resistance, total porosity, and pore volume were determined in classes of macropores $(\varnothing>50 \mu \mathrm{m})$, mesopores $(\varnothing=50$ to $0.5 \mu \mathrm{m})$, and micropores $(\varnothing<0.5 \mu \mathrm{m})$. In samples collected at the same locations in the layer 0.02$0.07 \mathrm{~m}$ deep, the saturated hydraulic conductivity, arithmetic mean diameter of air-dried (AMDad) and water-stable (AMDws) aggregates, and the aggregates' stability index (AEI = AWDws/AWDad) were determined. The physical attributes were determined in a routine analysis using the methods described in VEIGA (2011). Shoot dry mass of cover crops and weeds was determined in an area of $2 \times 1 \mathrm{~m}$ at each plot.

Results of the chemical and physical analyses were subjected to an analysis of variance for each layer individually. Statistical significance was determined by an $\mathrm{F}$ test, and comparison of means was performed using Tukey's test $(\mathrm{P}<0.05)$.

\section{RESULTS AND DISCUSSION}

There were significant differences between sampling positions (row and inter-row) for most physical attributes determined in the two-sampled layers (Table 2), as also observed by DALLA ROSA et al. (2013) and VALOIS et al. (2014). Bulk density was higher in the inter-rows, which can be explained by both machinery and equipment traffic in that position, and by surface soil disturbance through hand weeding in the vine rows. Lower porosity was also observed, primarily due to the decreased volume of macropores, since the volume of micropores increase with increasing bulk density, and mesopores are not affected by this attribute.

Penetration resistance (PR) was higher at inter-rows than at rows from $0.02-0.07 \mathrm{~m}$ deep, associated with the traffic of light machinery and equipment which determines surface compaction and increased bulk density in this layer, as also observed by VALOIS et al. (2014) and DALLA ROSA et al.(2013).Cover crops had no effect in deterring or reducing this compaction at the time of this study, agreeing with the results obtained in croplands by LAURANI et al. (2004), NICOLOSO et al. (2008) and SILVEIRA JUNIOR et al. (2012) or in vineyards by DALLA ROSA et al. (2013).

The greater volume of macropores in the surface layer of the vine rows was reflected in a higher saturated hydraulic conductivity (SHC), 
Table 2 - Soil physical and chemical attributes at layers $0.02-0.07$ and $0.12-0.17 \mathrm{~m}$ deep, at rows and inter-rows of a vineyard, in the third year of soil management with manual weeding, mechanical mowing, and winter cover crops.

\begin{tabular}{|c|c|c|c|c|}
\hline \multirow[b]{2}{*}{ Attribute (Unit) } & \multicolumn{2}{|c|}{-0.02-0.07m--------- } & \multicolumn{2}{|c|}{ 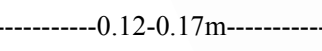 } \\
\hline & Row & Inter-row & Row & Inter-row \\
\hline Saturated hydraulic conductivity $\left(\mathrm{cm} \mathrm{h}^{-1}\right)$ & $165 \mathrm{a}$ & $27 b$ & - & - \\
\hline AMDad (mm) & $2.95 b$ & $3.38 \mathrm{a}$ & - & - \\
\hline AMDws (mm) & $2.55 \mathrm{~b}$ & $2.71 \mathrm{a}$ & - & - \\
\hline Aggregate stability index & $0.86 \mathrm{a}$ & $0.80 \mathrm{~b}$ & - & - \\
\hline Clay $\left(\mathrm{g} \mathrm{kg}^{-1}\right)$ & $500 \mathrm{~b}$ & $615 \mathrm{a}$ & $626 \mathrm{a}$ & $641 \mathrm{a}$ \\
\hline Bulk density $\left(\mathrm{kg} \mathrm{dm}^{-3}\right)$ & $0.86 \mathrm{~b}$ & $1.02 \mathrm{a}$ & $1.02 \mathrm{~b}$ & $1.08 \mathrm{a}$ \\
\hline Resistance to penetration ( $\mathrm{MPa})$ & $1.11 \mathrm{~b}$ & $1.43 \mathrm{a}$ & $1.49 \mathrm{a}$ & $1.52 \mathrm{a}$ \\
\hline Total posority $\left(\mathrm{m}^{3} \mathrm{~m}^{-3}\right)$ & $0.622 \mathrm{a}$ & $0.603 \mathrm{a}$ & $0.604 \mathrm{a}$ & $0.590 \mathrm{a}$ \\
\hline Macroporosity $\left(\mathrm{m}^{3} \mathrm{~m}^{-3}\right)$ & $0.217 \mathrm{a}$ & $0.127 b$ & $0.153 a$ & $0.097 \mathrm{~b}$ \\
\hline Mesoporosity $\left(\mathrm{m}^{3} \mathrm{~m}^{-3}\right)$ & $0.061 b$ & $0.081 \mathrm{a}$ & $0.054 \mathrm{~b}$ & $0.071 \mathrm{a}$ \\
\hline Microporosity $\left(\mathrm{m}^{3} \mathrm{~m}^{-3}\right)$ & $0.344 b$ & $0.395 \mathrm{a}$ & $0.396 b$ & $0.422 \mathrm{a}$ \\
\hline Organic matter $\left(\mathrm{g} \mathrm{kg}^{-1}\right)$ & $46 a$ & $42 b$ & $37 \mathrm{a}$ & $40 \mathrm{a}$ \\
\hline $\mathrm{pH}$ in water & $6.1 \mathrm{a}$ & $5.6 b$ & $5.0 \mathrm{a}$ & $5.2 \mathrm{a}$ \\
\hline Extractable $\mathrm{P}\left(\mathrm{mg} \mathrm{dm}^{-3}\right)$ & $46.2 \mathrm{a}$ & $5,9 \mathrm{~b}$ & $8.9 \mathrm{a}$ & $3.4 \mathrm{~b}$ \\
\hline Exchangeable $\mathrm{K}\left(\mathrm{mg} \mathrm{dm}^{-3}\right)$ & $297 \mathrm{a}$ & $94 b$ & $242 \mathrm{a}$ & $60 \mathrm{~b}$ \\
\hline Exchangeable $\mathrm{Ca}\left(\mathrm{cmol}_{\mathrm{c}} \mathrm{dm}^{-3}\right)$ & $8.4 \mathrm{a}$ & $5.8 \mathrm{~b}$ & $3.5 \mathrm{a}$ & $3.5 \mathrm{a}$ \\
\hline Exchangeable $\mathrm{Mg}\left(\mathrm{cmol}_{\mathrm{c}} \mathrm{dm}^{-3}\right)$ & $4.8 \mathrm{a}$ & $3.6 b$ & $2.2 \mathrm{a}$ & $2.3 \mathrm{a}$ \\
\hline Extractable $\mathrm{Zn}\left(\mathrm{mg} \mathrm{dm}^{-3}\right)$ & $35.0 \mathrm{a}$ & $5.0 \mathrm{~b}$ & $5.3 \mathrm{a}$ & $2.0 \mathrm{~b}$ \\
\hline Extractable $\mathrm{Cu}\left(\mathrm{mg} \mathrm{dm}^{-3}\right)$ & $48.2 \mathrm{a}$ & $29.7 b$ & $23.7 \mathrm{a}$ & $16.9 \mathrm{~b}$ \\
\hline $\mathrm{H}+\mathrm{Al}\left(\mathrm{cmol}_{\mathrm{c}} \mathrm{dm}^{-3}\right)$ & $2.7 \mathrm{~b}$ & $4.5 \mathrm{a}$ & $7.5 \mathrm{a}$ & $7.8 \mathrm{a}$ \\
\hline $\mathrm{CEC}\left(\mathrm{cmol}_{\mathrm{c}} \mathrm{dm}^{-3}\right)$ & $16.6 \mathrm{a}$ & $14.2 \mathrm{~b}$ & $13.9 \mathrm{a}$ & $13.8 \mathrm{a}$ \\
\hline Exchangeable $\mathrm{Al}\left(\mathrm{cmol}_{\mathrm{c}} \mathrm{dm}^{-3}\right)$ & $0.0 \mathrm{~b}$ & $0.2 \mathrm{a}$ & $1.8 \mathrm{a}$ & $1.3 b$ \\
\hline Al saturation (\%) & $0.1 b$ & $2.3 \mathrm{a}$ & $22.7 \mathrm{a}$ & $19.7 \mathrm{a}$ \\
\hline Base saturation $(\%)$ & $83.6 \mathrm{a}$ & $68.0 \mathrm{~b}$ & $46.3 \mathrm{a}$ & $43.9 b$ \\
\hline
\end{tabular}

"-": Not determined in the layer 0.12-0.17m deep; AMDad: arithmetic mean diameter of air-dried aggregates; AMDws: arithmetic mean diameter of water-stable aggregates; CEC: cation exchange capacity; Means followed by the same letter in the row, within each attribute and layer, do not differ significantly (Tukey test, $\mathrm{P}<0.05$ ).

on average more than six times the value observed in inter-rows. As also determined by MORLAT \& JACQUET (1993) in vineyards in France and CONRADIE et al. (2002) in South Africa, higher SHC determines a rapid internal drainage of gravitational water and is associated with the lower volume of meso - and micropores, and results in less storage of available water for the crop. Cover crop treatments affected the soil SHC both in rows and in inter-rows (Table 3). In rows, the SHC was reduced in treatments without cover crops (manual mowing and mechanical weeding), while in the inter-rows, the lowest values were observed in oat, corn spurrey, rye, and turnip. Grasses showed high values for SHC at vine rows, but only the ryegrass differed from the others at inter-rows. The high values of SHC observed in areas with white clover and red clover are probably due to the action of the weeds' root system that had developed in the area, since the growth of these winter cover crops was poor (Table1). The higher values of SHC, associated with de development of the cover crops in spring, can cause reduction in water availabity in the upper soil layer, led the grapevine to modify its rooting and explore other soil zones in deep soils (CELETTE et al., 2008), as the soil in this trial, avoiding significant reduction in vine vegetative growth and yield as observed by RUIZ-COLMENERO et al.(2011).

A higher arithmetic mean diameter of air-dried (AWDad) and water-stable (AMDws) aggregates in the superficial layer was observed at the inter-row, but the aggregates stability index (ASI) was lower in this position. This indicated that at the inter-row, the aggregates were formed on the basis of mechanical approximation of the particles resulting from the plastic soil deformation by machinery and 
Table 3 - Saturated hydraulic conductivity (SHC) in samples collected at the layer $0.02-0.07 \mathrm{~m}$ deep at rows and inter-rows of a vineyard in the third year of soil management with manual weeding, mechanical mowing, and winter cover crops.

\begin{tabular}{|c|c|c|c|}
\hline \multirow[t]{2}{*}{ Treatment } & Inter-row & Row & Mean \\
\hline & \multicolumn{3}{|c|}{ 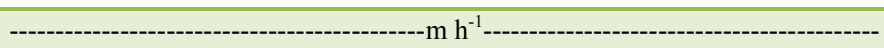 } \\
\hline Manual weeding & 6.61 & 15.03 & $10.82 \mathrm{ab}$ \\
\hline Mechanical mowing & 9.07 & 16.05 & $12.56 \mathrm{a}$ \\
\hline White clover & 8.96 & 13.10 & $11.03 \mathrm{ab}$ \\
\hline Red clover & 7.46 & 12.53 & $9.99 \mathrm{ab}$ \\
\hline Turnip & 8.30 & 11.91 & $10.11 \mathrm{ab}$ \\
\hline Corn spurrey & 7.96 & 13.53 & $10.74 \mathrm{ab}$ \\
\hline Common vetch & 8.20 & 13.07 & $10.63 \mathrm{ab}$ \\
\hline Black oat & 8.88 & 11.81 & $10.34 \mathrm{ab}$ \\
\hline Rye & 6.64 & 11.74 & $9.19 b$ \\
\hline Ryegrass & 8.46 & 11.95 & $10.20 \mathrm{ab}$ \\
\hline Mean & $8.05 b$ & $13.07 \mathrm{a}$ & \\
\hline
\end{tabular}

Means followed by the same letter in the column do not differ significantly (Tukey test, $\mathrm{P}<0.05$ ).

equipment traffic, without effective participation of temporary or permanent cementing agents in this process, as also observed by VEIGA et al. (2009) in a soil of the same class. These authors showed a significant positive correlation between bulk density with AMDad and AMDws but not with ASI, indicating that the first two were influenced by the degree of soil compaction. Additionally, DALLA ROSA et al. (2013) observed that the management of cover crops by mowing showed higher aggregate stability than when they are desiccated.

Considering the physical attributes of the soil as a whole, it appears that soil quality is better at vine rows than at inter-rows, which is related to surface compaction promoted by the machinery and equipment traffic at inter-rows. However, the values of attributes associated with soil compaction do not reach critical levels for vine root growth in any position or layers, according to parameters pointed out by REICHERT et al. (2007).

There were significant differences between the sampling positions for all chemical attributes in the layer $0.0-0.1 \mathrm{~m}$ deep, and in some of the attributes in the layer 0.1-0.2m deep (Table 2). Results can be explained by the history of the vineyard's fertilization prior to the experiment, with superficial application of lime and fertilizers in a band along the vine row and their merger with superficial hoe. High levels of extractable $\mathrm{Cu}$ and $\mathrm{Zn}$ reported in the rows can also be associated with the application of pesticides (VALLADARES et al., 2009), since the higher spray volume is applied in this band where the grape bunches are located.

The highest values of extractable $\mathrm{P}$ and $\mathrm{Zn}$, and exchangeable $\mathrm{Ca}$ and $\mathrm{Mg}$ (Table 4) were observed with white clover and red clover, in which there was little development of cover crops (Table1). These values can be explained by the greater ability of weeds to cycle these nutrients in comparison with the species of cover crops studied. These results corroborated those obtained by BUGG et al. (1996), who reported that chemical changes in the soil were associated with differential abilities of species to establish themselves in the vineyards, which may even produce less biomass than weeds. Increase in $\mathrm{K}$ and total inorganic $\mathrm{N}$ was observed in superficial soil layers after cultivation of some cover crops compared to the control (FOURIE et al., 2016). On the other hand, cover crop P, K and Mg uptake did not reduce the soil availability of those nutrients and did not influence their concentration in the grapevine (PÉREZ-ÁLVAREZ et al. (2015).

No differences were observed in the levels of organic matter in the soil between treatments, unlike the results obtained by FARIA et al. (2004) in a sandy soil of the São Francisco River; by STEENWERT \& BELINA (2008) on a medium-textured soil in California; and by FOURIE et al. (2016) on a sandy soil in the semi-arid Olifants River Valley of the Western Cape. This can be explained mainly by the relatively short time of experimentation, and by the high original organic matter content in this study's 
Table 4 - Contents of extractable $\mathrm{P}$ and $\mathrm{Zn}$ and exchangeable $\mathrm{Ca}$ and $\mathrm{Mg}$ at the layers $0.0-0.1 \mathrm{~m}$ and $0.1-0.2 \mathrm{~m}$ deep in the third year of soil management with manual weeding, mechanical mowing, and winter cover crops in a vineyard.

\begin{tabular}{|c|c|c|c|c|c|c|c|c|}
\hline \multirow{3}{*}{ Treatment } & \multicolumn{2}{|c|}{-------Extractable P------- } & \multicolumn{2}{|c|}{------Extractable Zn------ } & \multicolumn{2}{|c|}{----Exchangeable Ca---- } & \multicolumn{2}{|c|}{----Exchangeable Mn---- } \\
\hline & $0.0-0.1 \mathrm{~m}$ & $0.1-0.2 \mathrm{~m}$ & $0.0-0.1 \mathrm{~m}$ & $0.1-0.2 \mathrm{~m}$ & $0.0-0.1 \mathrm{~m}$ & $0.1-0.2 \mathrm{~m}$ & $0.0-0.1 \mathrm{~m}$ & $0.1-0.2 \mathrm{~m}$ \\
\hline & \multicolumn{4}{|c|}{ 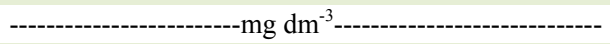 } & \multicolumn{4}{|c|}{ 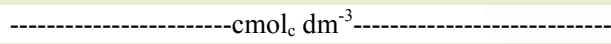 } \\
\hline Manual weeding & $15.4 \mathrm{bc}$ & $5.4 \mathrm{ab}$ & $14.8^{\mathrm{ns}}$ & $4.6 \mathrm{ab}$ & $6.7 \mathrm{abc}$ & $4.3^{\mathrm{ns}}$ & $4.0 \mathrm{ab}$ & $2.8^{\mathrm{ns}}$ \\
\hline Mechanical mowing & $22.6 \mathrm{bc}$ & $5.4 \mathrm{ab}$ & 24.9 & $2.7 \mathrm{~b}$ & $7.4 \mathrm{abc}$ & 3.4 & $4.3 \mathrm{ab}$ & 2.2 \\
\hline White clover & $42.8 \mathrm{ab}$ & $11.9 \mathrm{a}$ & 31.7 & $5.5 \mathrm{ab}$ & $8.2 \mathrm{ab}$ & 4.3 & $4.9 \mathrm{a}$ & 2.7 \\
\hline Red clover & $53.3 \mathrm{a}$ & $9.0 \mathrm{ab}$ & 35.7 & $6.6 \mathrm{a}$ & $8.4 \mathrm{a}$ & 3.9 & $4.7 \mathrm{ab}$ & 2.4 \\
\hline Turnip & $28.1 \mathrm{abc}$ & $5.5 \mathrm{ab}$ & 13.7 & $2.4 \mathrm{~b}$ & $6.7 \mathrm{abc}$ & 3.1 & $3.9 \mathrm{~b}$ & 2.0 \\
\hline Corn spurrey & $16.0 \mathrm{bc}$ & $4.6 \mathrm{~b}$ & 13.2 & $2.6 \mathrm{~b}$ & $6.4 \mathrm{c}$ & 2.8 & $4.1 \mathrm{ab}$ & 1.8 \\
\hline Common vetch & $26.7 \mathrm{abc}$ & $5.2 \mathrm{ab}$ & 19.6 & $4.7 \mathrm{ab}$ & $7.4 \mathrm{abc}$ & 3.5 & $4.1 \mathrm{ab}$ & 2.3 \\
\hline Black oat & $27.2 \mathrm{abc}$ & $4.6 \mathrm{~b}$ & 14.8 & $2.3 \mathrm{~b}$ & $6.9 \mathrm{abc}$ & 3.2 & $4.0 \mathrm{~b}$ & 2.0 \\
\hline Rye & $15.2 \mathrm{bc}$ & $5.3 \mathrm{ab}$ & 11.2 & $2.4 \mathrm{~b}$ & $6.8 \mathrm{abc}$ & 3.6 & $4.1 \mathrm{ab}$ & 2.4 \\
\hline Ryegrass & $12.8 \mathrm{c}$ & $4.7 \mathrm{~b}$ & 20.8 & $2.8 \mathrm{ab}$ & $6.4 \mathrm{bc}$ & 3.1 & $3.9 \mathrm{~b}$ & 2.0 \\
\hline
\end{tabular}

soil, a condition in which additional increments by input of organic material are smaller.

\section{CONCLUSION}

Winter cover crops presented different dry mass production in the vineyard, and the weeds' dry mass production was high among some cover crops, contributing significantly to the total dry mass production.

Winter cover crops changed few soil chemical and physical attributes and did not differentiate from the management of spontaneous vegetation by manual weeding or mechanical mowing in the inter-row. Conversely, in the vine row there was higher bulk density and penetration resistance where manual weeding and mechanical mowing was used.

The vine rows had values of soil physical and chemical attributes most suitable to vine development, except for the high values of extractable $\mathrm{Zn}$ and $\mathrm{Cu}$.

\section{REFERENCES}

BAUMGARTNER, K. et al. Cover-crop systems affect weed communities in a California vineyard. Weed Science, v.56, n.4, p.596-605, 2008. Available from: <http://www.bioone.org/ doi/abs/10.1614/WS-07-181.1>. Accessed: Apr. 25, 2016. doi: 10.1614/WS-07-181.1.

BORDELON, B.P.; WELLER S.C. Preplant cover crops affect weed and vine growth in first-year vineyards. Hortscience, v.32, n.6, p.1040-1043, 1997. Available from: <http://hortsci. ashspublications.org/content/32/6/1040.full.pdf + html $>$. Accessed: Apr. 15, 2016.

BUGG, R.L. et al. Comparison of 32 cover crops in an organic vineyard on the north coast of California. Biological Agriculture
\& Horticulture, v.13, n.1, p.63-81, 1996. Available from: <http:// www.tandfonline.com/doi/abs/10.1080/01448765.1996.9754766>. Accessed: Apr. 15, 2016. doi: 10.1080/01448765.1996.9754766.

CELETTE, F.et al. Spatial and temporal changes to the water regime of a Mediterranean vineyard due to the adoption of cover cropping. European Journal of Agronomy, v.29, n.4, p.153-162, 2008. Available from: <http://www.sciencedirect.com/science/ article/pii/S1161030108000464>. Accessed: Apr. 25, 2016. doi: 10.1016/j.eja.2008.04.007.

CONRADIE, W.J. et al. Effect of different environmental factors on the performance of Sauvignon Blanc grapevines in the Stellenbosch/Durbanville Districts of South Africa. I. Geology, climate, phenology and grape composition. South African Journal for Enology and Viticulture, v.23, n.2, p.78-91, 2002. Available from: <http://www.sawislibrary.co.za/dbtextimages/ ConradieWJ.pdf $>$. Accessed: Apr. 25, 2016.

DALLA ROSA, J. et al. Soil physical properties and grape yield influenced by cover crops and management systems. Revista Brasileira de Ciência do Solo, v.37, n.5, p.1352-1360, 2013. Available from: $<\mathrm{http}: / / \mathrm{www}$. scielo.br/scielo.php?script=sci_artte xt\&pid=S0100-06832013000500024>. Accessed: Apr. 25, 2016. doi: $10.1590 / \mathrm{S} 0100-06832013000500024$.

EMPRESABRASILEIRADE PESQUISAAGROPECUÁRIA. Centro Nacional de Pesquisa de Solos. Solos do Estado de Santa Catarina. Rio de Janeiro: EMBRAPA/CNPS, 2004. Mapa color. (Embrapa Solos. Boletim de Pesquisa e Desenvolvimento; n. 46) CD-ROM.

FARIA, C.M.B. et al. Green manuring grapevine with legumes in the submiddle São Francisco River Valley. Revista Brasileira de Ciência do Solo, v.28, n.4, p.641-648, 2004. Available from: <http://www. scielo.br/pdf/\%0D/rbcs/v28n4/21789.pdf>. Accessed: Apr. 15, 2016.

FOURIE, J.C.et al. Cover crop management in a Sauvignon Blanc/Ramsey vineyard in the semi-arid Olifants River Valley, South Africa. 3. Effect of different cover crops and cover crop management practices on the organic matter and macro-nutrient contents of a sandy soil. South African Journal of Enology and Viticulture, v.28, n.2, p.92-100, 2007. Available from: 
$<$ http://www.journals.ac.za/index.php/sajev/article/view/1464>. Accessed: Aug 05, 2016. doi: 10.21548/28-2-1464.

LAURANI, R.A. et al. Pore distribution of a eutroferric red latosol in the initial stage of a no tillage system. Engenharia Agrícola, v.24, n.2. p.347-354, 2004. Available from: <http://www.scielo.br/ pdf/eagri/v24n2/v24n2a13>. Accessed: Apr. 25, 2016.

LOPES, C.M. et al. Combining cover cropping with deficit irrigation in a Mediterranean low vigor vineyard. Scientia Horticulturae, v.129, n.4, p.603-612, 2011. Available from: <http://www. sciencedirect.com/science/article/pii/S0304423811002330>. Accessed: Apr. 15, 2016. doi: 10.1016/j.scienta.2011.04.033.

MEURER, E.J. et al. Fenômenos de sorção em solos. In. MEURER, E.J.(Ed.). Fundamentos de química do solo. 4.ed. Porto Alegre: Evangraf, 2010. p.107-148.

MORLAT, R.; JACQUET, A. The soil effects on the grapevine root system in several vineyards of the Loire valley (France). VITIS-Journal of Grapevine Research, v.32, n.1, p.35-42, 1993. Available from: < http://pub.jki.bund.de/index.php/VITIS/article/ view/5176>. Accessed: Apr. 15, 2016.

NICOLOSO, R.S. et al. Efficiency of mechanical and biological chiseling in the improvement of physical attributes of a heavy clay oxisol and the increment of soybean yield. Revista Brasileira de Ciência do Solo, v.32, n.4. p.1723-1734, 2008. Available from: $<$ http://www.scielo. br/scielo.php?script=sci_arttext\&pid=S0100-06832008000400037> Accessed: Apr. 15, 2016. doi: 10.1590/S0100-06832008000400037.

OLMSTEAD, M.A. et al. Evaluation of potential cover crops for inland Pacific Northwest vineyards. American Journal of Enology and Viticulture, v.52, n.4, p.292-303, 2001. Available from: $<$ http://naldc. nal.usda.gov/naldc/download.xhtml $\mathrm{id}=23566 \&$ content $=\mathrm{PDF}>$. Accessed: Apr. 15, 2016.

PANDOLFO, C. et al. Atlas climático digital do Estado de Santa Catarina. Florianópolis: Epagri, 2002. CD-ROM.

PÉREZ-ÁLVAREZ, E.P. et al. Soil nutrient availability under cover crops and its delayed effects on vine, must, and wine in a Tempranillo vineyard. American Journal of Enology and Viticulture, v.66, n.3, p.311-320, 2015. Available from: <http:// www.ajevonline.org/content/early/2015/04/24/ajev.2015.14092>. Accessed: Aug. 28, 2016. doi: 10.5344/ajev.2015.14092.

REICHERT, J.M. et al. Compactação do solo em sistemas agropecuários e florestais: identificação, efeitos, limites críticos e mitigação. In: CERETTA, C.A. et. al. (Eds.). Tópicos em ciência do solo. Viçosa, MG: Sociedade Brasileira de Ciência do Solo,2007. V.5, p.49-134.

REICOSKY, D.C.; FORCELLA, F. Cover crop and soil quality interactions in agroecosystems. Journal of Soil and Water Conservation, v.53, n.3, p.224-229, 1998.Available from: <http:// www.jswconline.org/content/53/3/224.short>. Accessed: Apr. 15, 2016. doi: $10.2489 /$ jswc.71.1.12

RUIZ-COLMENERO, M. et al. Soil and water conservation dilemmas associated with the use of green cover in steep vineyards. Soil and
Tillage Research, v.117, p.211-223, 2011. Available from: <http:// www.sciencedirect.com/science/article/pii/S016719871100170X>. Accessed: Sep. 15, 2016. doi: 10.1016/j.still.2011.10.004.

SILVEIRA JUNIOR, S.D. et al. Physical quality of untilled oxisol subjected to mechanical and biological decompaction. Revista Brasileira de Ciência do Solo, v.36, n.6, p.18541867, 2012. Available from: <http://www.scielo.br/scielo. php script $=$ sci arttext $\&$ pid $=\mathrm{S} 0100-06832012000600020>$. Accessed: Aüg. 08, 2016. doi: 10.1590/S010006832012000600020\#sthash.ISeutB1i.dpuf.

SMITH, R. et al. Vineyard floor management affects soil, plant nutrition, and grape yield and quality. California Agriculture, v.62, n.4, p.184-190, 2008. Available from: <http://calag.ucanr. edu/Archive/?article=ca.v062n04p184> . Accessed: Aug. 20, 2016 doi: $10.3733 /$ ca.v062n04p184.

STEENWERTH, K.; BELINA, K.M. Cover crops enhance soil organic matter, carbon dynamics and microbiological function in a vineyard agroecosystem. Applied Soil Ecology, v.40, n.2, p.359369, 2008. Available from: <http://www.sciencedirect.com/science/ article/pii/S0929139308000978>. Accessed: Aug. 22, 2016. doi: 10.1016/j.apsoil.2008.06.006.

TEDESCO, M.J. et al. Análise de solo, plantas e outros materiais. Porto Alegre: Departamento de Solos, UFRGS, 1995. 174p. (Boletim Técnico, 5).

VALLADARES, G.S.et al. Spatial variability and copper and zinc availability in vineyards and nearby soils. Bragantia, v.68, n.3, p.733-742, 2009. Available from: <http://www.scielo. br/scielo.php?pid=S0006-87052009000300021\&script $=$ sci abstract\&tlng=pt $>$. Accessed: Sep. 25, 2016. doi: 10.1590/S000687052009000300021 .

VALOIS, C.M. et al. Physical attributes of a Haplic Cambisol in vineyards subjected to different traffic intensities. Revista Brasileira de Ciência do Solo, v.38, n.4, p.1256-1267, 2014. Available from: <http://www.scielo.br/scielo.php?pid=S0100$06832014000400022 \&$ script $=$ sci_abstract\&tlng $=$ pt $>$. Accessed: Sep. 22, 2016. doi: 10.1590/S0100-06832014000400022\#sthash. Q4CCeZNo.dpuf.

VAN HUYSSTEEN, L. et al. The effect of cover crop management on soil conditions and weed control in a Colombar Vineyard in Oudtshoorn. South African Journal of Enology and Viticulture, v.5, n.1, p.7-17, 2017. Available from: <http://www.journals.ac.za/index.php/sajev/ article/view/2364>. Accessed: Jul. 15, 2017. doi: 10.21548/5-1-2364.

VEIGA, M. Metodologia para coleta de amostras e análises físicas do solo. Florianópolis: Epagri, 2011. 52p. (Epagri. Boletim Técnico, 156).

VEIGA, M. et al. Aggregate stability as affected by short and long-term tillage systems and nutrient sources of a Hapludox in Southern Brazil. Revista Brasileira de Ciência do Solo, v.33, n.4, p.767-777, 2009. Available from: $<$ http://www.scielo.br/scielo.php?script=sci arttext\&pid $=$ S0100-06832009000400003 $>$. Accessed: Aug. 22, 2016. doi: 10.1590/S0100-06832009000400003\#sthash.GnsVIZwH.dpuf. 